\title{
Optimisation of growth conditions for continuous culture of the hyperthermophilic archaeon Thermococcus hydrothermalis and development of sulphur-free defined and minimal media
}

\author{
Anne Postec, Patricia Pignet, Valérie Cueff-Gauchard, Anne Schmitt,
} Joël Querellou and Anne Godfroy*

\author{
Laboratoire de Microbiologie des Environnements Extrêmes, UMR 6197 Ifremer, Centre de Brest, BP 70, 29280 \\ Plouzané, France \\ *: Corresponding author : agodfroy@ifremer.fr
}

\begin{abstract}
:
The hyperthermophilic archaeon Thermococcus hydrothermalis was cultivated in continuous culture in a gas-lift bioreactor in the absence of elemental sulphur on both proteinaceous and maltosecontaining media. Optimal conditions $(\mathrm{pH}$, temperature and gas flow rate), determined on complex media that yielded maximal growth rate and maximal steady state cell density, were obtained at 80degreesC, $\mathrm{pH} 6$ and gas sparging at $0.2 \vee \mathrm{v}(-1) \min (-1)$. Higher steady state cell densities were obtained on a medium containing maltose and yeast extract. In order to design a defined and minimal media, the nutritional requirements of $\mathrm{T}$ hydrothermalis were then investigated using continuous culture in the absence of elemental sulphur in the gas-lift bioreactor. First, the complex nutriments were replaced and a defined medium containing maltose, 19 amino acids and the two nitrogenous bases adenine and thymine, was determined. Secondly, selective feedings and withdrawal of amino acids showed requirements for 14 amino acids.
\end{abstract}




\section{Abstract}

The hyperthermophilic archaeon Thermococcus hydrothermalis was cultivated in continuous culture in a gas-lift bioreactor in the absence of elemental sulphur on both proteinaceous and maltose containing media. Optimal conditions $(\mathrm{pH}$, temperature and gas flow rate), determined on complex media that yielded maximal growth rate and maximal steady state cell density were obtained at $80^{\circ} \mathrm{C}, \mathrm{pH}$ and gas sparging at $0.2 \mathrm{v} \cdot \mathrm{v}^{-1} \cdot \mathrm{min}^{-1}$. Higher steady state cell densities were obtained on a media containing maltose and yeast extract. In order to design a defined and minimal media, the nutritional requirements of $T$. hydrothermalis were then investigated using continuous culture in the absence of elemental sulphur in the gas-lift bioreactor. First, the complex nutriments were replaced and a defined medium containing maltose, 19 amino acids and the two nitrogenous bases adenine and thymine, was determined. Secondly, selective feedings and withdrawal of amino acids showed requirements for 14 amino acids.

Keywords : Thermococcus hydrothermalis, gas-lift bioreactor, culture optimisation, defined and minimal media

\section{Introduction}

Within the hyperthermophilic archaea, species belonging to the order Thermococcales, have been extensively studied in both fields of physiology and genomics. In addition to their phylogenetic and ecological interest, hyperthermophilic archaea were identified early on, as potentially interesting organisms for the production of thermostable enzymes. Thermococcales species can grow in the absence of elemental sulphur but for most of these species, the addition of sulphur greatly enhances growth in closed culture. Raven et al. (1992) showed that a glass 
gas-lift bioreactor could be used to grow Pyrococcus furiosus at high cell densities in the absence of elemental sulphur. This experimental system was then used to develop a defined and minimal media that supported the growth of $P$. furiosus [12]. Using the same system, Pyrococcus abyssi ST549 was cultivated at high cell density on complex media containing yeast extract and peptone in the absence of elemental sulphur [7].

T. hydrothermalis was first isolated from a deep-sea hydrothermal vent of the East Pacific Rise. It has been shown to grow at temperatures ranging from 55 to $100^{\circ} \mathrm{C}$; it is strictly anaerobic chemoorganotrophic. Descriptive study of this strain [6] revealed that $T$. hydrothermalis was able to grow on both proteinaceous substrates (or a mixture of amino acids) and on maltose, and a recent study confirmed that it could use maltose (in the presence of a small amount of yeast extract) and amino acids as carbon and energy sources in the presence of elemental sulphur.

Several enzymatic activities have been identified and characterised in $T$. hydrothermalis : $\alpha$-amylase [9], pullulanase [5], $\alpha$-glucosidase [8] and alcohol dehydrogenase [2]. In this paper, we determined the optimal conditions for the cultivation $T$. hydrothermalis in a gas-lift bioreactor in the absence of elemental sulphur and investigated its nutritional requirements in order to develop a defined and minimal medium.

\section{Materials and methods}

\subsection{Strain}

T. hydrothermalis type strain AL662 (CNCM-I1319) was isolated in our laboratory [6]. 


\subsection{Media}

The growth medium was SME $Y(1) P(2)$ medium [19] modified according to Sharp and Raven $[11,18]$. In further experiments, peptone was replaced by maltose at 2.5 or $5 \mathrm{g.l}^{-1}$ [SME Y(1) mal(5) or SME Y(1) mal(2.5) media]. When yeast extract was replaced by the 20 amino acids, the latter were first used each at a concentration of $0.1{\mathrm{~g} . \mathrm{I}^{-1}}^{-}[\mathrm{SME} 20 \mathrm{AA}(0.1) \mathrm{mal}(2.5)]$, then, they were used at the same concentrations as in a $1 \mathrm{g.l}^{-1}$ aqueous suspension of yeast extract [SME 19AA[Y] mal(2.5) ]. Quantitative estimations of the concentration of each free amino acid in an aqueous

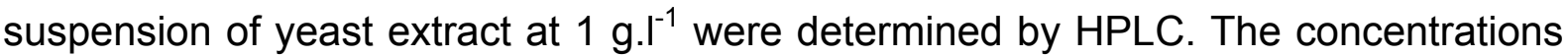
(per litre) were : Ala 42 mg, Arg 22 mg, Asn 14 mg, Asp 6.5 mg, Gln none, Glu 47 mg, Gly 16 mg, His 4 mg, Ile 25 mg, Leu 42 mg, Lys 23 mg, Met 4 mg, Phe 24 mg, Pro $14 \mathrm{mg}$, Ser $18 \mathrm{mg}$, Thr $12 \mathrm{mg}$, Trp $4 \mathrm{mg}$, Tyr $10 \mathrm{mg}$ and Val $30 \mathrm{mg}$. Cys used as reductant, was maintained at $0.5 \mathrm{~g} \mathrm{I}^{-1}$. The media were sterilised by filtration (Sartroban $0.22 \mu \mathrm{m}$ filters, Sartorius) into 20 I Nalgene bottles previously sterilised by autoclaving.

\subsection{Growth conditions}

Closed cultures were performed in $100 \mathrm{ml}$ serum vial containing $50 \mathrm{ml}$ of medium and sulphur as previously described [6]. Continuous culture experiments were performed using a gas-lift bioreactor, sparged with nitrogen as previously described by Raven $[7,11,12,18]$. The 2-litre volume glass vessel and Teflon top plate were fabricated by Radleys (UK). Temperature was controlled by a heated circulating bath filled with water, and temperature was monitored with a standard PT100 probe covered with Teflon. The $\mathrm{pH}$ was monitored using a combination gel $\mathrm{pH}$ electrode (Mettler Toledo) and acid and base were added with two peristaltic pumps (Masterflex). $\mathrm{pH}$ and temperature were controlled by a 4-20 mA controller and AFS 
Biocomand system from New Brunswick (Nimjgen, Netherlands). Fresh medium feeding and culture draw-off were performed using peristaltic pumps (Masterflex). Unless otherwise indicated, continuous cultures were carried out at $80^{\circ} \mathrm{C}$ and $\mathrm{pH} 6$, according to the descriptive study of the strain. Unless otherwise indicated, the dilution rate was $0.2 \mathrm{~h}^{-1}$ according to the previously determined growth rate [6] and under nitrogen sparging at $0.2 \mathrm{v} \cdot \mathrm{v}^{-1} \cdot \mathrm{min}^{-1}$.

\subsection{Determination of cell density}

Cell numbers were determined by direct cell counting using a Thoma cell $(0.02 \mathrm{~mm}$ depth) under a phase contrast Olympus model BH-2 microscope. When necessary,

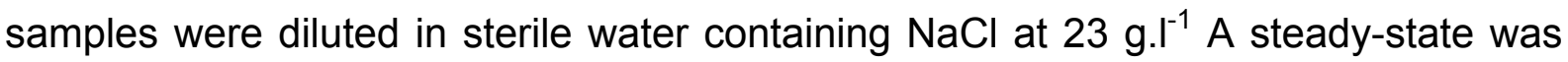
considered to be obtained when the cell densities remained effectively constant for a period in excess of three culture volume changes, corresponding to $15 \mathrm{~h}$ at a dilution rate of $0.2 \mathrm{~h}^{-1}[11]$

\subsection{Growth rate determination}

To determine the specific growth rate of $T$. hydrothermalis on the different media, batch culture experiments were carried out in the gas-lift bioreactor. A steady state continuous culture under the above culture conditions was washed out in order to lower significantly cell density. Medium feeding and drawing off were then stopped, and growth under batch conditions was followed by regular cell counting (every 15 min, 3 counts per sample). Growth rate were determined by performing a linear regression along the logarithmic part of the growth curve. Where enough data were available, growth rate confidence limits are given (+/- $2 \times$ standard errors). Wash out experiments were performed first to determine growth rates according to the formula $\left[1 / x(d x / d t)=\mu_{\max }-D\right][4]$, but problems with the reliability of media delivery rate 
measurement at high dilution rates $(D \geq 2)$ were shown to significantly affect growth rate calculations.

\subsection{Amino acids and maltose analysis by HPLC}

The amino acids and maltose in the culture medium were analysed by means of HPLC (Alliance 2690; Waters), as described by Wery et al. [22].

\section{Results}

3.1 Determination of the optimal conditions for the growth of $T$. hydrothermalis in continuous culture on SME Y(1)P(2) medium

Optimal conditions of $\mathrm{pH}(\mathrm{pH} 6)$ and temperature $\left(80-85^{\circ} \mathrm{C}\right)$ conditions for the growth of $T$. hydrothermalis were previously determined, in flask, on a complex medium in the presence of elemental sulphur [6]. These conditions $\left(\mathrm{pH} 6\right.$ and $\left.80^{\circ} \mathrm{C}\right)$ were the first conditions used for the cultivation of $T$. hydrothermalis in the gas-lift bioreactor. Good growth was observed with a steady state cell densities ranging from $8 \times 10^{8}$ to $1 \times 10^{9}$ cell.ml ${ }^{-1}$ at dilution rate of $0.2 \mathrm{~h}^{-1}$. The effect of gas sparging was studied by varying the nitrogen flow from 0.1 to $0.3 v \cdot v^{-1} \cdot \mathrm{min}^{-1}$. Maximal steady state cell density was obtained at $0.2 \mathrm{v} \cdot \mathrm{v}^{-1} \cdot \mathrm{min}^{-1}$. The effect of higher gas flow rates could not be tested due to the build up of surface foam. We then examined the effect of temperature and $\mathrm{pH}$ on maximal steady state cell densities. Figure 1 shows that steady state cell density dramatically decreases when $\mathrm{pH}$ is lowered to 4 and to a lesser degree at $\mathrm{pH} 5$. At $\mathrm{pH}$ 8, foam formation prevented further experiment and no significant difference in maximal steady state cell densities was observed at $\mathrm{pH} 6$ and 7. Temperature effects were tested from $70^{\circ}$ to $95^{\circ} \mathrm{C}$ at $\mathrm{pH}$ 6. Significant effect (compared to $80^{\circ} \mathrm{C}$ ) was observed at $70^{\circ}, 90^{\circ}$ and cell concentration dramatically decreased at $95{ }^{\circ} \mathrm{C}$ without reaching a new equilibrium state (not shown). No significant difference was observed between 80 and $85^{\circ} \mathrm{C}$. To determine the effects 
of both temperature and $\mathrm{pH}$ on the growth of $T$. hydrothermalis under these conditions, maximal growth rates were determined for some combination of $\mathrm{pH}$ and temperature on the complex medium SME $\mathrm{Y}(1) \mathrm{P}(2)$ (figure2). The higher maximal growth rate $\left(2.7 \mathrm{~h}^{-1}\right)$ and the highest steady state cell density were obtained at $\mathrm{pH} 6$ and at $80^{\circ} \mathrm{C}$. At $\mathrm{pH} 6$, growth started immediately, without a latent phase. At $\mathrm{pH} 7$, growth rate was slightly lower than at $\mathrm{pH} 6$, and a latent phase of 20 min was noticeable. At $\mathrm{pH} 5$, growth rates were considerably lower. At both $\mathrm{pH} 6$ and 7, the growth started earlier and high maximal growth rate was observed at $80^{\circ} \mathrm{C}$. Maximal growth rate at optimal $\mathrm{pH}$ and temperature was determined during the early part of the logarithmic of growth $\left(\mu_{\max }=2.7 \mathrm{~h}^{-1}\right)$ and, in fact a decrease of the growth rate $\left(\mu_{\max }=1.2 \mathrm{~h}^{-1}\right)$ was often observed after $45 \mathrm{~min}$ of culture. To confirm the existence of these two growth phases, other experiments were carried out by washing out the culture in order to obtain lower initial cell densities (around $1 \times 10^{6}$ cells. ml ${ }^{-1}$ compared to $3 \times 10^{7}$ cells. $\mathrm{ml}^{-1}$ in previous experiments). Three growth curves were obtained. All showed an initial rapid growth phase with a maximal growth rate of $3.03(+/-0.06) \mathrm{h}^{-1}$ corresponding to a generation time of $14 \mathrm{~min}$, then growth rate decreased to $1.23(+/-$ $0.02) \mathrm{h}^{-1}$, corresponding to a generation time of $35 \mathrm{~min}$. The high growth rate was confirmed with a short continuous culture experiment were dilution rate was increased up to $2 \mathrm{~h}^{-1}$ : under these conditions, a steady state cell density of $6.3 \times 10^{7}$ cell. $\mathrm{ml}^{-1}$ was achieved

\subsection{Growth of T. hydrothermalis in continuous culture on maltose}

Previous studies have shown that $T$. hydrothermalis could grow on a medium containing maltose and yeast extract [6]. When T. hydrothermalis was grown on SME Y(1) mal(5) medium, in the gas-lift bioreactor a higher maximal steady state cell 
density $\left(1.7 \times 10^{9}\right)$ was observed, compared to SME $\mathrm{Y}(1) \mathrm{P}(2)$ medium, at a dilution rate of $0.2 \mathrm{~h}^{-1}$ and gas sparging of $0.2 \mathrm{v} \cdot \mathrm{v}^{-1} \cdot \mathrm{min}^{-1}$. Yeast extract concentration in the culture medium was then lowered from $1 \mathrm{~g} . \mathrm{I}^{-1}$ to $0.5 \mathrm{~g} . \mathrm{I}^{-1}$ and $0.25 \mathrm{~g} . \mathrm{I}^{-1}$ and again high steady state cell densities were obtained, respectively $1.1 \times 10^{9}$ and $4.75 \times 10^{8}$.cell.ml 1. Gas sparging up to $0.5 \mathrm{v} \cdot \mathrm{v}^{-1} \cdot \mathrm{min}^{-1}$ had no effect on the maximal steady state cell density in the SME $Y(0.5)$ mal(5) medium and no foam formation was observed at

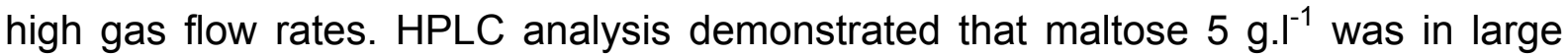

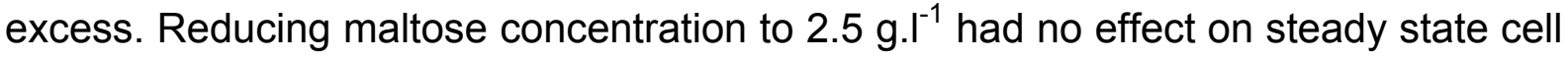
density. Maximal growth rate on SME Y(1) mal(2.5) medium was $1.72(+/-0.05) \mathrm{h}^{-1}$, corresponding to a generation time of $24 \mathrm{~min}$. On this medium, no slowing of the growth was observed.

\subsection{Defined medium determination}

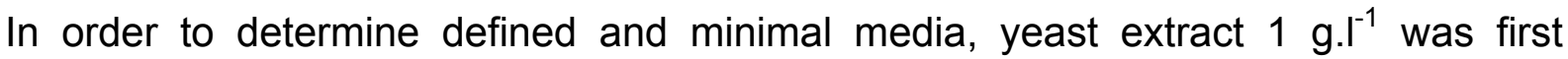
replaced by the 20 amino acids, each at a concentration of $0.1 \mathrm{~g}^{-1}{ }^{-1}$ "SME mal(2.5) 20AA(0.1)" medium, except for cysteine, used as reductant, at a concentration of 0.5 g. $\mathrm{I}^{-1}$. This resulted in a dramatically decrease in cell density to $5.0 \times 10^{6} \mathrm{cell}^{\mathrm{m}} \mathrm{m}^{-1} \mathrm{after}$ 24 hours of culture, without reaching a stationary state. Then, 19 amino acids were added, each at the same concentration as in an aqueous solution of yeast extract at $1 \mathrm{g.I}^{-1}$. On this medium "SME 19AA [Y] mal (2.5) ", a stationary state was obtained with a maximal cell density at $2.7 \times 10^{7}$ cell. $\mathrm{ml}^{-1}$. However the resulting cell density was rather low compared with the density obtained on the medium SME $Y(1)$ mal(2.5), suggesting that at least one important element, present in yeast extract was lacking in the defined medium. The effect of nitrogenous bases, thymine, adenine, uracile and cystosine was then tested each at the concentration of $10 \mathrm{mg}^{-1}{ }^{-1}$. The 
dilution rate was lowered from 0.2 to $0.1 \mathrm{~h}^{-1}$ in this experiment, in order to begin with a higher initial cell density and to reduce the wash-out risk in the absence of growth. The addition of the 2 nitrogenous bases adenine and thymine resulted in a $10 \mathrm{X}$ greater steady state cell density, compared to that obtained in their absence. When the dilution rate was increased to $0.2 \mathrm{~h}^{-1}$, a steady state cell density of $6.2 \times 10^{8}$ cell. $\mathrm{ml}^{-1}$ was achieved. A growth rate of $1.1 \mathrm{~h}^{-1}$, corresponding to a generating time of 38 min, was achieved during the continuous culture of $T$. hydrothermalis on the defined medium SME 19AA [Y] mal (2.5) $+\mathrm{A}+\mathrm{T}$.

\subsection{Minimal media determination}

A requirement for essential amino acids was determined previously (not shown), by cultivation of $T$. hydrothermalis on SME 20AA medium lacking individual amino acids in closed batch culture in the presence of elemental sulphur. Under these conditions, amino acids are used as both carbon and nitrogen sources. No growth was observed in the absence of Val, Thr, Met, Phe, Ile, Leu, Arg, Trp, Tyr, and Lys. Amino acid requirements were tested in the absence of sulphur in a continuous culture on the defined medium. First, all amino acids have been removed from the defined medium

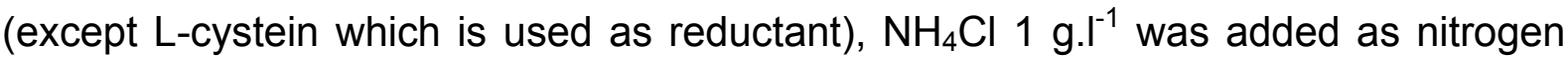

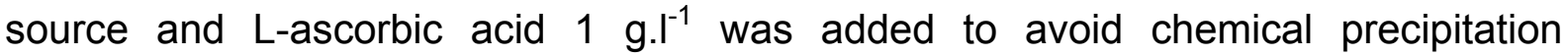
according to Raven and Sharp [12]. No growth was observed in the absence of amino acids in the medium, indicating that at least one of the amino acids was essential for growth of the strain. Then, amino acids were added and withdrawn from the defined medium by biosynthetic pathway group. An equilibrium state was obtained with a cell concentration of $2.2 \times 10^{8} \mathrm{cell}^{\mathrm{ml}}{ }^{-1}$ when Gly and Ser were omitted together. A very low cell density $\left(4.6 \times 10^{6}\right.$ cell. $\left.\mathrm{ml}^{-1}\right)$ was achieved when Ala, Leu and 
Val were deleted. These results suggested that Ser and Gly have no effect whereas at least one of the amino acids Ala, Leu or Val was important for growth. No stationary state was reached when the Glu, Gln, Pro, and Arg group; the Phe, Tyr, Trp and His group, and the Asp, Asn, Met, Thr, and Ile group were withdrawn, suggesting that each of these groups contained at least one essential amino acid for the growth of $T$. hydrothermalis in the gas-lift bioreactor.

The 9 amino acids (Ala, Asn, Asp, Glu, Gln, Gly, His, Pro, Ser), previously shown to be not essential for the growth of $T$. hydrothermalis in closed culture in the presence of sulphur, when omitted individually, were deleted as a group from the defined medium. Cell density decreased dramatically, without reaching a stationary state. Among these amino acids, HPLC analysis showed that Ala, Asn and His were entirely consumed during culture in the defined medium. The addition of Ala, Asn and His allowed a stabilisation of cell density at about $2.0 \times 10^{7} \mathrm{cell}^{\mathrm{m} \mathrm{ml}^{-1}}$. In the end, only 6 amino acids could be omitted: Asp, Glu, Gly, Pro, Ser and Gln (not present in yeast extract). Vitamin requirements were tested by elimination of all vitamins from the "SME 14 AA, mal (2.5) +A +T" media and from the defined medium. In both cases there was no effect on the growth of $T$. hydrothermalis. Similarly the removal of maltose was tested by cultivating the strain on the medium "SME $14 \mathrm{AA},+\mathrm{A}+\mathrm{T}$ +vitamins". A cell density decrease was observed and no stationary state could be reached. While $T$. hydrothermalis growth on the minimal medium (composition given in Table 1) was comparable to the growth on complex media there was considerable variation in steady state cell densities between experiments. Also we observed better growth on the minimal medium after several days of growth on the defined medium than following direct transition from the complex media to the minimal media. 


\section{Discussion}

The present study provides conditions for the growth of $T$. hydrothermalis at high cell densities under controlled conditions. The cultivation of this strain in the absence of elemental sulphur using a gas-lift bioreactor was shown to be efficient on both complex and defined media. This confirms the organism's ability to use both complex substrates or maltose as carbon and energy sources in the absence of elemental sulphur. On the complex medium, containing both yeast extract and peptone, $T$. hydrothermalis exhibited very rapid growth, and high steady state cell density could be maintained for a long period. On this medium growth began very quickly then slowed. This was not observed on other media that contained yeast extract alone or yeast extract and maltose, and could be due to a preferential first use of a more efficient substrate present in peptone. Maltose allowed growth at high cell densities, even when yeast extract concentration in the medium was lowered to $0.25 \mathrm{~g}^{-\mathrm{I}^{-1}}$. However total elimination of yeast extract led to a dramatic decrease in cell concentration demonstrating that growth on maltose alone is not possible. We were able to replace the complex yeast extract with a mixture of 19 amino acids and adenine and thymine and then with a mixture of 14 amino acids and adenine and thymine. This led to the determination of defined and minimal media. The replacement of yeast extract by the 20 amino acids each at $0.1 \mathrm{~g}^{-\mathrm{I}^{-1}}$ led to a washing out of the culture, while their addition at the same concentration as free amino acids in 1 g..$^{-1}$ yeast extract allowed growth. This might be explained by competition between amino acids for amino acid uptake. Growth on the 20 amino acids as sole carbon and energy sources occurred in closed vessels culture in the presence of elemental sulphur, while dramatic a decrease was observed on both the defined and minimal media without maltose in the absence of elemental sulphur, suggesting that 
amino acid utilisation as sole carbon and energy sources did not occurred in the absence of elemental sulphur, as it was demonstrated for $P$. furiosus [1]

Our results confirm the importance of effective cultivation methods for addressing physiological issues related to the growth of heterotrophic hyperthermophiles. Growth of heterotrophic hyperthermophiles in continuous culture was previously reported for P. furiosus [12] and for Thermococcus litoralis and the bacterial species Thermotoga maritima [14-16], for both the optimisation of growth conditions and the determination of defined or minimal media. The availability of defined media can allow the direct observation of the utilisation of individual nutrients the organism's ability to respond to the addition of a selected substrate and increase the production of thermostable enzymes of basic research or industrial interest. The existence of a wall effect was reported for both $T$. litoralis and $T$. maritima by Rinker and Kelly [15]. In this study increasing the dilution rate up to $2 \mathrm{~h}^{-1}$ (in wash out experiments for determination of maximal growth rate) did not result in the wash out the culture suggesting the existence of such a wall effect. However the determination of maximal growth rate in batch growth experiments showed that this apparent wall effect (i.e. stabilisation of cell concentrations during wash out experiments) corresponded in fact to the establishment of a new steady state at a higher dilution rate where growth rate was superior to the applied dilution rate.

The high growth rates observed here may be of ecological importance since they suggest that species belonging to the Thermococcales can grow very quickly when conditions are favourable. This could permit rapidly colonisation of new favourable habitats. In situ colonisation experiments using "vent cap" chambers have shown that Thermococcales were the dominant archaeal species $[3,10,13]$ and diversity analysis of hydrothermal samples such as chimney fragments showed 
Thermococcales, in most samples [20,21], even in the inner parts of a chimney walls [17]. These data suggest that Thermococcales and probably other heterotrophic hyperthermophiles may play an important role in the degradation of the organic matter in the hydrothermal vent ecosystem.

\section{Acknowledgements}

We want to thank Dr Neil Raven and Pr Richard Sharp for welcoming one of us (AG) in their laboratory and for allowing us to transfer the gas-lift bioreactor technology to our laboratory. We also thank Pr S. Kim Juniper for helpful reading of the manuscript. 
Table1:

\begin{tabular}{|c|c|}
\hline Compounds & | Concentration (per liter) \\
\hline $\mathrm{NaCl}$ & $28 \mathrm{~g}$ \\
\hline L-cystein & $0.5 \mathrm{~g}$ \\
\hline Resazurin & $0.5 \mathrm{mg}$ \\
\hline $\mathrm{MgSO}_{4}, 7 \mathrm{H}_{2} \mathrm{O}$ & $1.8 \mathrm{mg}$ \\
\hline $\mathrm{Mg} \mathrm{Cl}_{2}, 6 \mathrm{H}_{2} \mathrm{O}$ & $1.4 \mathrm{mg}$ \\
\hline $\mathrm{MnSO}_{4}, 4 \mathrm{H}_{2} \mathrm{O}$ & $9 \mathrm{mg}$ \\
\hline $\mathrm{ZnSO}_{4}, 7 \mathrm{H}_{2} \mathrm{O}$ & $2.5 \mathrm{mg}$ \\
\hline $\mathrm{NiCl}_{2}, 6 \mathrm{H}_{2} \mathrm{O}$ & $2.5 \mathrm{mg}$ \\
\hline $\operatorname{AlK}\left(\mathrm{SO}_{4}\right)_{2}, 12 \mathrm{H}_{2} \mathrm{O}$ & $0.3 \mathrm{mg}$ \\
\hline $\mathrm{CoCl}_{2}, 6 \mathrm{H}_{2} \mathrm{O}$ & $0.3 \mathrm{mg}$ \\
\hline $\mathrm{CuSO}_{4}, 5 \mathrm{H}_{2} \mathrm{O}$ & $0.15 \mathrm{mg}$ \\
\hline $\begin{array}{l}\mathrm{CaCl}_{2}, 2 \mathrm{H}_{2} \mathrm{O} \\
\mathrm{NaBr}\end{array}$ & $56 \mathrm{mg}$ \\
\hline $\begin{array}{l}\mathrm{NaBr} \\
\mathrm{KCl}\end{array}$ & $\begin{array}{l}25 \mathrm{mg} \\
16 \mathrm{mg}\end{array}$ \\
\hline $\mathrm{KI}$ & $10 \mathrm{mg}$ \\
\hline $\mathrm{SrCl}_{2}, 6 \mathrm{H}_{2} \mathrm{O}$ & $4 \mathrm{mg}$ \\
\hline $\mathrm{K}_{2} \mathrm{HPO}_{4}$ & $500 \mathrm{mg}$ \\
\hline $\mathrm{H}_{3} \mathrm{BO}_{3}$ & $7.5 \mathrm{mg}$ \\
\hline $\mathrm{Na}_{2} \mathrm{WO}_{4}, 2 \mathrm{H}_{2} \mathrm{O}$ & $3.3 \mathrm{mg}$ \\
\hline $\mathrm{Na}_{2} \mathrm{MoO}_{4}, 2 \mathrm{H}_{2} \mathrm{O}$ & $0.15 \mathrm{mg}$ \\
\hline $\mathrm{Na}_{2} \mathrm{SeO}_{3}$ & $0.005 \mathrm{mg}$ \\
\hline $\begin{array}{l}\mathrm{FeCl}_{2}, 4 \mathrm{H}_{2} \mathrm{O} \\
\text { Amino acids }\end{array}$ & 10 mg \\
\hline Asn & $14 \mathrm{mg}$ \\
\hline His & $4 \mathrm{mg}$ \\
\hline Arg & $22 \mathrm{mg}$ \\
\hline Thr & $12 \mathrm{mg}$ \\
\hline Ala & $42 \mathrm{mg}$ \\
\hline Tyr & $10 \mathrm{mg}$ \\
\hline Val & $30 \mathrm{mg}$ \\
\hline Met & $4 \mathrm{mg}$ \\
\hline Ile & $25 \mathrm{mg}$ \\
\hline Leu & $42 \mathrm{mg}$ \\
\hline Phe & $24 \mathrm{mg}$ \\
\hline Trp & $4 \mathrm{mg}$ \\
\hline Lys & $23 \mathrm{mg}$ \\
\hline Maltose & $2.5 \mathrm{~g}$ \\
\hline Nitrogenous bases & \\
\hline Adenine & $10 \mathrm{mg}$ \\
\hline Thymine & $10 \mathrm{mg}$ \\
\hline
\end{tabular}




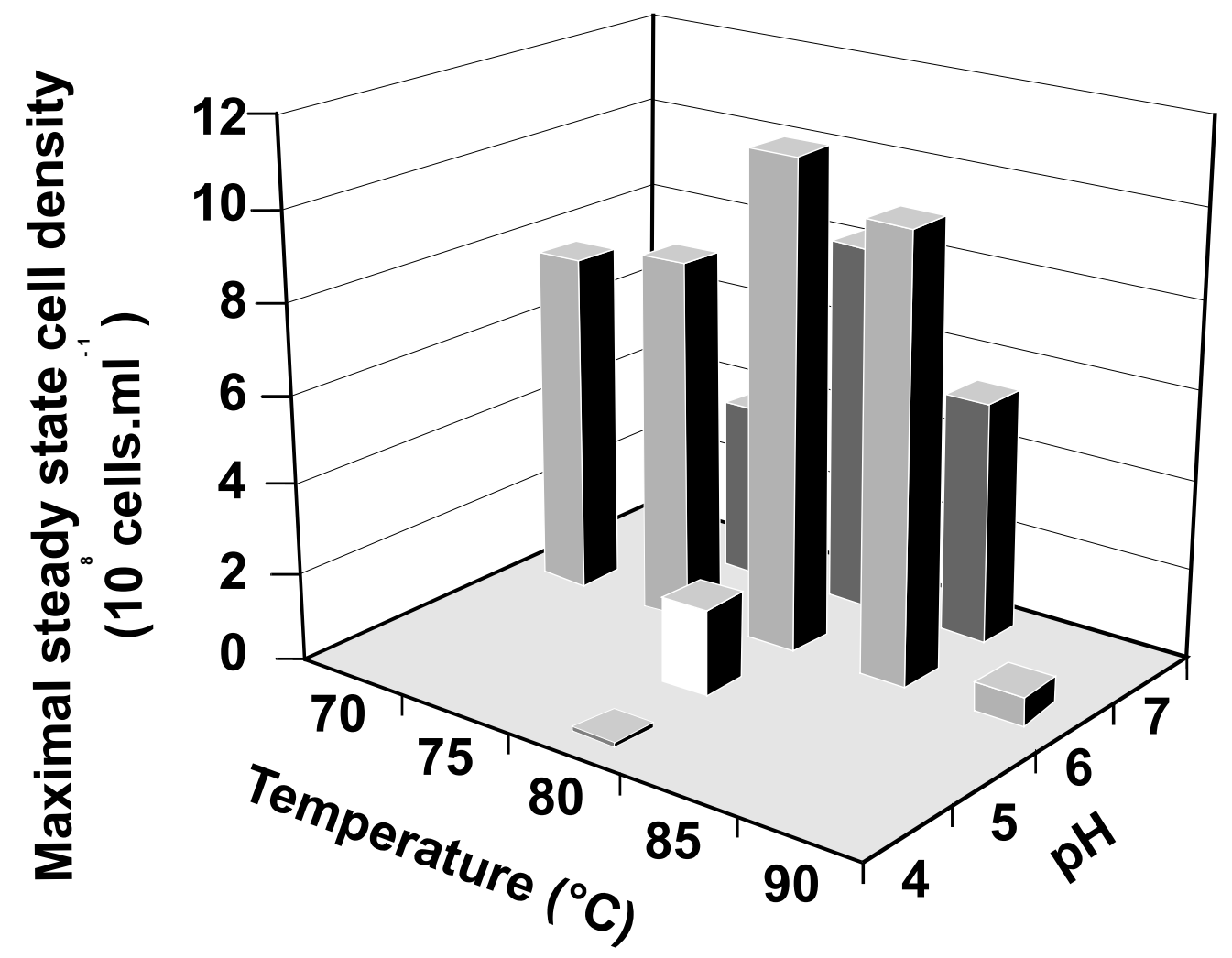

Figure 1

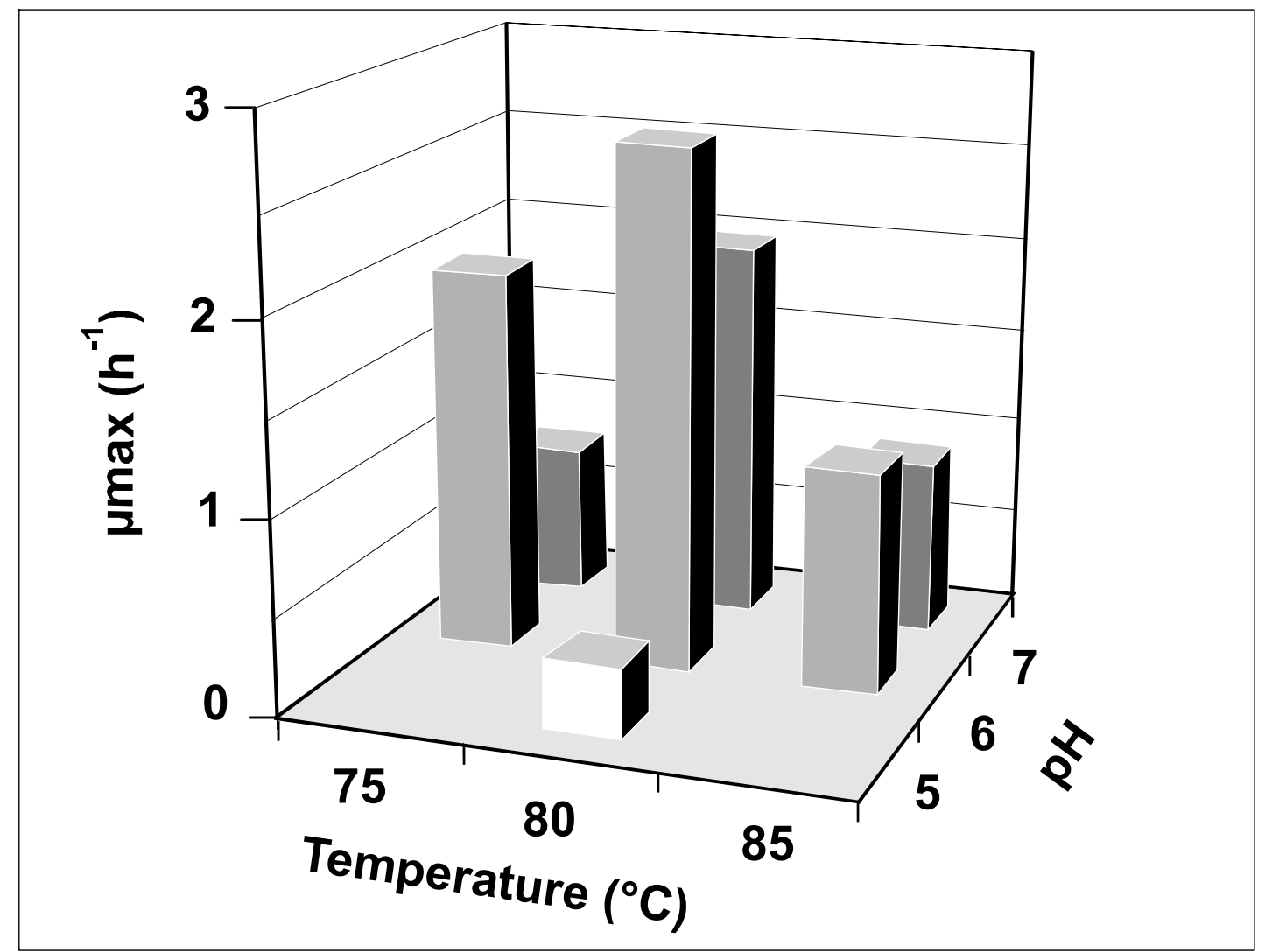

Figure 2 


\section{Legends of figures}

Table 1: Composition of the minimal medium.

Figure 1: Effect of $\mathrm{pH}$ and temperature on the maximal steady state cell density of $T$. hydrothermalis grown on SME $\mathrm{Y}(1) \mathrm{P}(2)$ medium in continuous culture $\left(D=0 ; 2 \mathrm{~h}^{-1}\right)$ in the gas-lift bioreactor.

Figure 2: $\quad$ Effect of $\mathrm{pH}$ and temperature on maximal growth rate of $T$. hydrothermalis grown on SME $\mathrm{Y}(1) \mathrm{P}(2)$ medium cultivated in the gaslift bioreactor.

\section{References}

[1] M.W.W. Adams, J.F. Holden, A.L. Menon, G.J. Schut, A.M. Grunden, C. Hou, A.M. Hutchins, F.E. Jenney, C. Kim, K.S. Ma, G.L. Pan, R. Roy, R. Sapra, S.V. Story,M. Verhagen, Key role for sulfur in peptide metabolism and in regulation of three hydrogenases in the hyperthermophilic archaeon Pyrococcus furiosus, J. Bacteriol. 183 (2001) 716-724.

[2] E. Antoine, J.L. Rolland, J.P. Raffin, J. Dietrich, Cloning and over-expression in Escherichia coli of the gene encoding NADPH group III alcohol dehydrogenase from Thermococcus hydrothermalis, Eur. J. Biochem. 264 (1999) 880-889.

[3] E. Corre, A.-L. Reysenbach,D. Prieur, $\varepsilon$-Proteobacterial diversity from a deepsea hydrothermal vent on the Mid-Atlantic Ridge, FEMS Microbiol. Lett. 205 (2001) 329-335.

[4] L.C. Duarte, A.P. Nobre, F.M. Girio,M.T. Amaral-Collaço, Determination of the kinetic parameters in continuous cultivation by Debaromyces hanseniigrown on xylose, Biotechnol. Techn. 8 (1994) 859-864.

[5] M. Erra-Pujada, P. Debeire, F. Duchiron,M.J. O'Donohue, The Type II Pullulanase of Thermococcus hydrothermalis: Molecular Characterization of the Gene and Expression of the Catalytic Domain, J. Bacteriol. 181 (1999) 3284-3287.

[6] A. Godfroy, F. Lesongeur, G. Raguénès, J. Quérellou, E. Antoine, J.-R. Meunier, J. Guezennec,G. Barbier, Thermococcus hydrothermalis sp. nov., a new hyperthermophilic Archaeon isolated from deep-sea hydrothermal vent., Int. J. Syst. Bacteriol. 47 (1997) 622-626.

[7] A. Godfroy, N.D.H. Raven,R.J. Sharp, Physiology and continuous culture of the hyperthermophilic deep-sea vent archaeon Pyrococcus abyssi ST549, FEMS Microbiol. Lett. 186 (2000) 127-132. 
[8] E. Legin, C. Ladrat, A. Godfroy, G. Barbier,F. Duchiron, Thermostable amylolytic enzymes of thermophilic microorganisms from deep-sea hydrothermal vents. Some properties of a thermostable alpha-glucosidase,, C. R. Acad. Sci. III. 320 (1998) 893-898.

[9] E. Leveque, B. Haye,A. Belarbi, Cloning and expression of an alpha-amylase encoding gene from the hyperthermophilic archaebacterium Thermococcus hydrothermalis and biochemical characterisation of the recombinant enzyme, FEMS Microbiol. Lett. 186 (2000) 67-71.

[10] O. Nercessian, A.-L. Reysenbach, D. Prieur,C. Jeanthon, Archaeal diversity associated with in situ samplers deployed on hydrothermal vents on the East Pacific Rise $\left(13^{\circ} \mathrm{N}\right)$, Environ. Microbiol. 5 (2003) 492-502.

[11] N. Raven, N. Ladwa,R. Sharp, Continuous culture of the hyperthermophilic archaeum Pyrococcus furiosus, Appl. Microbiol. Biotechnol. 38 (1992) 263267.

[12] N.D.H. Raven,R.J. Sharp, Development of defined and minimal media for the growth of the hyperthermophilic archaeon Pyrococcus furiosus Vc1, FEMS Microbiol. Lett. 146 (1997) 135-141.

[13] A.L. Reysenbach, K. Longnecker,J. Kirshtein, Novel bacterial and archaeal lineages from an in situ growth chamber deployed at a Mid-Atlantic Ridge hydrothermal vent, Appl. Environ. Microbiol. 66 (2000) 3798-3806.

[14] K.D. Rinker, C.J. Han,R.M. Kelly, Continuous culture as a tool for investigating the growth physiology of heterotrophic hyperthermophiles and extreme thermoacidophiles, J. Appl. Microbiol. 85 Suppl. S (1999) 118S-127S.

[15] K.D. Rinker,R.M. Kelly, Effect of carbon and nitrogen sources on growth dynamics and exopolysaccharide production for the hyperthermophilic Archaeon Thermococcus litoralis and Bacterium Thermotoga maritima, Biotechnol. Bioeng. 69 (2000) 537-547.

[16] K.D. Rinker,R.M. Kelly, Growth physiology of the hyperthermophilic Archaeon Thermococcus litoralis: Development of a sulfur-free defines medium, characterization of an exopolysaccaride, and evidence of biofilm formation, Appl. Environ. Microbiol. 62 (1996) 4478-4485.

[17] M.O. Schrenk, D.S. Kelley, J.R. Delaney,J.A. Baross, Incidence and Diversity of Microorganisms within the Walls of an Active Deep-Sea Sulfide Chimney, Appl. Environ. Microbiol. 69 (2003) 3580-3592.

[18] R.J. Sharp,N.D.H. Raven in: P.M. Rhodes,P.F. Stanbury, (Eds.)Applied Microbial Physiology : A practical approach IRL Press, Oxford University press.1997, pp. 23-51.

[19] K.O. Stetter, H. König,E. Stackebrandt, Pyrodictium gen. nov., a new genus of submarine disc-shaped sulfur-reducing archaebacteria growing optimally at $105^{\circ}$ C., System. Appl. Microbiol. 4 (1983) 535-551.

[20] K. Takai,K. Horikoshi, Molecular phylogenetic analysis of archaeal introncontaining genes coding for rRNA obtained from a deep-subsurface geothermal water pool, Appl. Environ. Microbiol. 65 (1999) 5586-5589.

[21] K. Takai, T. Komatsu, F. Inagaki,K. Orikoshi, Distribution of Archaea in a black smoker chimney structure, Appl. Environ. Microbiol. 67 (2001) 3618-3629.

[22] N. Wery, F. Lesongeur, P. Pignet, V. Derennes, M.-A. Cambon-Bonavita, A. Godfroy,G. Barbier, Marinitoga camini, gen. nov. , sp. nov., a rod-shaped bacterium belonging to the order Thermotogales, isolated from a deep-sea hydrothermal vent, Int. J. System. Evol. Microbiol. 51 (2001) 495-504. 